\section{DiscoverSys \\ Published by DiscoverSys \\ Risk factors for hepatitis B virus infections among pregnant women in East Lombok District}

\author{
Eka Faizaturrahmi, ${ }^{1}$ Luh Seri Ani, ${ }^{2 *}$ Komang Ayu Kartika Sari ${ }^{2}$
}

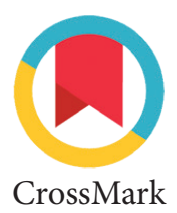

CrossMark

\begin{abstract}
Background and purpose: The World Health Organization (WHO) has set a target of $90 \%$ reduction in new hepatitis B infections by 2030 . The WHO program includes prevention of new infections, and increases testing uptake and treatment. In order to effectively foster prevention, it is necessary to understand the risk factors for transmission. This study aims to determine the risk factors of hepatitis B infection in pregnant women.
\end{abstract}

Methods: A case control study was carried out among 52 pregnant women with $\mathrm{HBsAg}(+)$ as cases and 104 pregnant women with $\mathrm{HBsAg}(-)$ as controls. The source of cases and controls was the register of pregnant women at the Pringgasela Public Health Center from January 2016 to 0 ctober 2017. Cases were selected using systematic random sampling from $67 \mathrm{HBsAg}(+)$ pregnant women and controls were selected in the same way from 1644 pregnant women with HBsAg (-). Cases and controls were matched by domicile. The data collected were age, age of first marriage, education, family income, parity, history of miscarriage, maternal or husband's history of working abroad, frequency of marriage, history of injection, surgery, blood transfusion and dental care. Data collection was carried out with a pre-tested questionnaire in April-May 2018 through interviews at the home of each respondent. Multivariate analysis with logistic regression was carried out to determine the adjusted odds ratio of each risk factor.

Results: Cases and controls characteristics were found to be similar in terms of age, domicile, education and income. Significant risk factors were the history of husband working abroad ( $\mathrm{AOR}=4.28 ; 95 \% \mathrm{Cl}$ : 1.6611.08), age of first marriage $\leq 19$ years ( $A O R=2.52 ; 95 \% \mathrm{Cl}: 1.16-5.48)$ and frequency of husband's marriage more than one time $(A O R=3.08$; 95\%(l: 1.35-7.08).

Conclusion: Husbands with history of working abroad, age of first marriage $<20$ years and frequency of husband's marriage more than one time were found to be the risk factors for hepatitis B infection in pregnant women. These factors require public health attention in order to reduce the transmission of hepatitis $B$.
${ }^{1}$ Hamzar Health Technical College, Lombok Timur,

${ }^{2}$ Department of Public Health and Preventive Medicine, Faculty of Medicine, Udayana University
*Correspondence to: Luh Seri Ani, Department of Public Health and Preventive Medicine, Faculty of Medicine, Udayana University luhseriani@yahoo.com

Keywords: Risk factors, hepatitis B infection, pregnant women, East Lombok

Cite This Article: Faizaturrahmi, E., Ani, L.S., Sari, K.A.K. 2018. Risk factors for hepatitis B virus infections among pregnant women in East Lombok District. Public Health and Preventive Medicine Archive 6(2): 108-113. D0I:10.15562/phpma.v6i2.113

\section{INTRODUCTION}

The burden of hepatitis B has been a global concern. The World Health Organization (WHO) estimates that 257 million or $3.5 \%$ of the population globally lives with chronic hepatitis B. ${ }^{1}$ In 2015 an estimated of 887,000 deaths were due to hepatitis $\mathrm{B}$ infection and mostly caused by cirrhosis and liver cancer. ${ }^{2}$ Hepatitis B can be transmitted vertically and horizontally. Vertical transmission occurs during the process of pregnancy, during and after the delivery. ${ }^{3}$ Horizontal transmission can be through blood, contaminated needles, saliva, vaginal secretions and semen fluid. ${ }^{2}$

The prevalence of people infected with hepatitis $\mathrm{B}$ in Western Pacific is 6.2\%, Africa 6.1\%, Eastern Mediterranean 3.3\% and Southeast Asia region 2.0\%. ${ }^{1}$ The reported prevalence of hepatitis B in Indonesia in 2017 was $7.1 \%$ and $2.7 \%$ among pregnant women. ${ }^{4}$ An estimated of 150 thousand infants have a $95 \%$ chance of suffering from chronic hepatitis (cirrhosis or liver cancer) each year, in the next 30 years. ${ }^{4}$ In 2016 the prevalence of hepatitis B (HBsAg+) among pregnant women was reported at $3.4 \%$ in West Nusa Tenggara
Province and 3\% in East Lombok District. The prevalence of hepatitis B in pregnant women in the Pringgasela Public Health Center was 3.0\% in 2015 and $3.4 \%$ in $2016 .{ }^{5}$

The WHO's target is a $90 \%$ reduction in new hepatitis B infections by $2030 .^{1}$ The programs carried out are prevention of new infections, testing and treatment. ${ }^{1}$ In order to ensure prevention efforts are effective, it is necessary to understand the risk factors for hepatitis B transmission. Studies in other countries show that the incidence of hepatitis B is related to several factors, namely age, ${ }^{6,7}$ education, ${ }^{8,9}$ parity, ${ }^{10,11}$ history of miscarriage, ${ }^{12,13}$ early age of first sexual intercourse, number of sexual partners $\geq 2,{ }^{6,9,10,14,15}$ injection history, ${ }^{16}$ and history of surgery. ${ }^{16,17}$ Studies on hepatitis B in Indonesia were conducted mainly among healthcare workers and young women, ${ }^{18,19}$ and more on hepatitis B management procedures during pregnancy and childbirth..$^{20,21}$ Publications on the association between hepatitis $B$ infection and age at first marriage, frequency of maternal and husband's 
marriage, and history of mother and husband working abroad remains limited.

The reported number of people in East Lombok District who worked abroad in the JanuaryFebruary period of 2012-2015 and 2016-2017 was ranked first in Indonesia, ${ }^{22,23}$ which was 15,408 people. ${ }^{24}$ Early marriage in East Lombok District also remains high, reaches $75.63 \%$ each year with an average age below 19-20 years, resulting in an increased divorce rate. ${ }^{24}$

This study aims to determine the association between hepatitis B infection among pregnant women with parity, history of miscarriage, maternal or husband's history of working abroad, age of first marriage, frequency of maternal or husband's marriage and injection history.

\section{METHODS}

A case control study was carried out among 52 pregnant women with $\mathrm{HBsAg}(+)$ as cases and 104 pregnant women with $\mathrm{HBsAg}(-)$ as controls. The number of samples was calculated with a confidence level of $95 \%$, an anticipated odds ratio of 2.0, relative precision of $40 \%$, and proportion of age of first marriage $<19$ among married women of $33.4 \%{ }^{25}$ The source of cases and controls was the register of pregnant women at the Pringgasela Public Health Center, East Lombok District, West Nusa Tenggara Province, from January 2016 to October 2017. The area of Pringgasela Public Health Center consists of 10 villages with a population of 53,135. Cases were selected using systematic random sampling from 67 pregnant women with HBsAg (+) and controls were selected in the same way from 1644 pregnant women with HBsAg (-). Cases and controls were matched by domicile. The data collected were age, age of first marriage, education, family income, parity, history of miscarriage, maternal or husband's history of working abroad, frequency of marriage, history of injection, surgery, blood transfusion and dental care.

Data collection was carried out from April-May 2018 through interviews with a questionnaire at the home of each respondent (pregnant women/ post-natal). The questionnaire was pre-tested with 10 pregnant women at the Pringgasela Public Health Center. The questionnaire consisted of three sections, namely the characteristics of the respondent, the possibility of sexual contact, and the possibility of blood contact. The characteristics of respondents section consisted of 27 questions, the possibility of sexual contact 20 questions and blood contact 10 questions. Family income was classified as "low" if they earned less than 1,400,000 and "high" if they earned equal or more than $1,400,000$ per month. This cut-off is based on the minimum standard wage in East Lombok District.

Multivariate analysis with logistic regression was carried out to determine the adjusted odds ratio of each risk factor. This study has been approved by the Ethics Committee of the Faculty of Medicine, University of Mataram on March 31, 2018.

\section{RESULTS}

Table 1 presents the distribution of cases and controls by age and domicile, and indicates that there is no significant difference in age $(p=0.55)$ and domicile $(\mathrm{p}=1.00)$.

Table 2 presents the crude OR of age, education, history of mother or husband's working abroad, family income, parity, history of miscarriage, age of first marriage, frequency of maternal or

Table 1 Distribution of cases and controls by age and domicile

\begin{tabular}{lccc}
\hline Characteristics & $\begin{array}{c}\text { Cases } \\
\mathbf{n}(\%)\end{array}$ & $\begin{array}{c}\text { Controls } \\
\mathbf{n}(\%)\end{array}$ & $\mathbf{p}$ \\
\hline $\begin{array}{l}\text { Age (years), mean } \pm \text { SD } \\
\text { Domicile }\end{array}$ & $29.6 \pm 5.6$ & $28.9 \pm 6.5$ & 0.55 \\
$\quad$ Jurit & $7(13.5)$ & & 1.00 \\
Rempung & $6(11.5)$ & $14(13.5)$ & $12(11.5)$ \\
Pengadangan & $10(19.2)$ & $20(19.2)$ \\
East Pringgasela & $3(5.8)$ & $6(5.8)$ \\
Jurit Baru & $3(5.8)$ & $6(5.8)$ \\
South Pringgasela & $7(13.5)$ & $14(13.5)$ \\
West Pengadangan & $3(5.8)$ & $6(5.8)$ \\
Aik Dewa & $7(13.5)$ & $14(13.5)$ \\
Pringgasela & $6(11.5)$ & $12(11.5)$ \\
Total & $52(100.0)$ & $104(100.0)$ \\
\hline
\end{tabular}


Table 2 Crude OR of risk factors for hepatitis B infection among pregnant women

\begin{tabular}{|c|c|c|c|c|c|c|c|}
\hline \multirow[b]{2}{*}{ Variables } & \multicolumn{2}{|c|}{ Cases } & \multicolumn{2}{|c|}{ Controls } & \multirow[b]{2}{*}{ Crude OR } & \multirow[b]{2}{*}{$95 \% \mathrm{Cl}$} & \multirow[b]{2}{*}{$\mathbf{p}$} \\
\hline & $n$ & $\%$ & $n$ & $\%$ & & & \\
\hline \multicolumn{8}{|l|}{ Age (years) } \\
\hline $17-24$ & 8 & 15.4 & 33 & 31.7 & 2.06 & $0.72-5.94$ & 0.18 \\
\hline $25-34$ & 33 & 63.4 & 49 & 47.1 & 0.74 & $0.32-1.73$ & 0.49 \\
\hline $35-42$ & 11 & 21.2 & 22 & 21.2 & 1.00 & & \\
\hline \multicolumn{8}{|l|}{ Education } \\
\hline$\leq$ Elementary & 21 & 40.4 & 44 & 42.3 & 1.08 & $0.49-2.36$ & 0.85 \\
\hline Junior high school & 14 & 26.9 & 27 & 26.0 & 0.99 & $0.42-2.37$ & 0.99 \\
\hline$\geq$ Senior high school & 17 & 32.7 & 33 & 31.7 & 1.00 & & \\
\hline \multicolumn{8}{|c|}{ History of respondent working abroad } \\
\hline Yes & 5 & 9.6 & 10 & 9.6 & 1.00 & $0.32-3.09$ & 1.00 \\
\hline No & 47 & 90.4 & 94 & 90.4 & 1.00 & & \\
\hline \multicolumn{8}{|c|}{ History of husband working abroad } \\
\hline Yes & 44 & 84.6 & 67 & 64.4 & 3.04 & $1.29-7.13$ & 0.01 \\
\hline No & 8 & 15.4 & 37 & 35.6 & 1.00 & & \\
\hline \multicolumn{8}{|l|}{ Family income } \\
\hline$<$ IDR $1,400,000$ & 21 & 40.4 & 51 & 49.0 & 0.70 & $0.36-1.38$ & 0.31 \\
\hline$\geq \operatorname{IDR} 1,400,000$ & 31 & 59.6 & 53 & 51.0 & 1.00 & & \\
\hline \multicolumn{8}{|l|}{ Parity } \\
\hline$>2$ & 22 & 42.3 & 23 & 22.1 & 2.58 & $1.26-5.30$ & 0.01 \\
\hline$\leq 2$ & 30 & 57.7 & 81 & 77.9 & 1.00 & & \\
\hline \multicolumn{8}{|l|}{ History of miscarriage } \\
\hline Yes & 9 & 17.3 & 17 & 16.3 & 1.07 & $0.44-2.60$ & 0.88 \\
\hline No & 43 & 82.7 & 87 & 83.7 & 1.00 & & \\
\hline \multicolumn{8}{|l|}{ Age of first marriage } \\
\hline$\leq 19$ years & 33 & 63.5 & 45 & 43.3 & 2.28 & $1.15-4.52$ & 0.02 \\
\hline$>19$ years & 19 & 36.5 & 59 & 56.7 & 1.00 & & \\
\hline \multicolumn{8}{|c|}{ Frequency of maternal marriage } \\
\hline$>1$ & 9 & 17.3 & 13 & 12.5 & 1.47 & $0.58-3.69$ & 0.42 \\
\hline$\leq 1$ & 43 & 82.7 & 91 & 87.5 & 1.00 & & \\
\hline \multicolumn{8}{|c|}{ Frequency of husband's marriage } \\
\hline$>1$ & 23 & 44.2 & 20 & 19.2 & 3.33 & $1.60-6.93$ & 0.00 \\
\hline$\leq 1$ & 29 & 55.8 & 84 & 80.8 & 1.00 & & \\
\hline \multicolumn{8}{|l|}{ History of injection } \\
\hline Yes & 31 & 59.6 & 67 & 64.4 & 0.82 & $0.41-1.62$ & 0.56 \\
\hline No & 21 & 40.4 & 37 & 35.6 & 1.00 & & \\
\hline \multicolumn{8}{|l|}{ History of surgery ${ }^{\star}$} \\
\hline Yes & 4 & 7.7 & 7 & 6.7 & 1.16 & $0.32-4.14$ & 1.00 \\
\hline No & 48 & 92.3 & 97 & 93.3 & 1.00 & & \\
\hline \multicolumn{8}{|c|}{ History of blood transfusion } \\
\hline Yes & 6 & 11.5 & 10 & 9.6 & 1.23 & $0.42-3.58$ & 0.71 \\
\hline No & 46 & 88.5 & 94 & 90.4 & 1.00 & & \\
\hline \multicolumn{8}{|l|}{ History of dental care } \\
\hline Yes & 17 & 32.7 & 23 & 22.1 & 1.71 & $0.82-3.59$ & 0.15 \\
\hline No & 35 & 67.3 & 81 & 77.9 & 1.00 & & \\
\hline
\end{tabular}

${ }^{*}$ Statistics test conducted with Fisher's Exact 
Table 3 Adjusted OR of risk factors for hepatitis B infection among pregnant women

\begin{tabular}{|c|c|c|c|}
\hline Variables & AOR & $95 \% \mathrm{Cl}$ & $\mathbf{p}$ \\
\hline \multicolumn{4}{|l|}{ Age (years) } \\
\hline $35-42$ & 1.00 & & \\
\hline $25-34$ & 0.69 & $0.27-1.78$ & 0.44 \\
\hline $17-24$ & 2.64 & $0.81-8.64$ & 0.11 \\
\hline \multicolumn{4}{|c|}{ History of husband working abroad } \\
\hline No & 1.00 & & \\
\hline Yes & 4.28 & $1.66-11.08$ & $<0.01$ \\
\hline \multicolumn{4}{|c|}{ Age of first marriage } \\
\hline$>19$ years & 1.00 & & \\
\hline$\leq 19$ years & 2.52 & $1.16-5.48$ & 0.02 \\
\hline \multicolumn{4}{|c|}{ Frequency of husband's marriage } \\
\hline$\leq 1$ & 1.00 & & \\
\hline$>1$ & 3.09 & $1.35-7.08$ & $<0.01$ \\
\hline \multicolumn{4}{|c|}{ History of dental care } \\
\hline No & 1.00 & & \\
\hline Yes & 2.17 & $0.92-5.11$ & 0.08 \\
\hline
\end{tabular}

husband's marriage, history of injection, surgery, blood transfusion, and dental care. All variables with $\mathrm{p}<0.25$ were analyzed using multivariate logistic regression. Table 3 shows that the significant risk factors for hepatitis B infection among pregnant women were husbands who have worked abroad ( $\mathrm{AOR}=4.28$; 95\%CI: 1.66-11.08), age of first marriage $\leq 19$ years $(\mathrm{AOR}=2.52$; 95\%CI: 1.16-5.55) and frequency of husband's marriage more than one time $(\mathrm{AOR}=3.09$; $95 \% \mathrm{CI}$ : $1.35-7.08)$.

\section{DISCUSSION}

Our study found that three variables potentially increase the risk of hepatitis B infection among pregnant women, namely the husband that had the history of working abroad, the age of first marriage $\leq 19$ years and the frequency of husband's marriage more than one time. While age, education, family income, parity, history of miscarriage, maternal history of working abroad, history of injection, surgery, blood transfusion and dental care were not significantly associated with hepatitis B infection among pregnant women. These results indicate the possibility of transmission through sexual contact, because transmission of the hepatitis B virus occurs due to inoculation through broken skin, or through mucosal contact with blood or other body fluids (especially vaginal fluids and semen) from an infected person. ${ }^{26,27}$
In our study pregnant women with husbands who had worked abroad were found to be more at risk for hepatitis $\mathrm{B}$ infection. This was probably related to mobility factors. A study in Germany indicated that migrants have a higher risk of being infected with hepatitis $\mathrm{B} .{ }^{28}$ The results of other studies show that individuals who are far from partner tend to seek new sexual partners.

In this study, we also found that pregnant women who had a husband that had been previously married more than one time were more at risk of being infected with hepatitis $B$. Another study conducted in China found that there was a significant association between pregnant women whose husbands had more than one wife with hepatitis $\mathrm{B}$ infection $(\mathrm{AOR}=5.80$; 95\%CI: 2.1-10.4). ${ }^{29}$ The study also found that wives with husbands who had a positive history of syphilis significantly increased the risk of hepatitis B infection (AOR=2.69; 95\%CI: 2.57-2.82) ${ }^{29}$

In our study, it was evident that getting married at 19 years or younger increased the risk of being infected with hepatitis B. This finding is consistent with a study conducted in Lagos, Nigeria stating that pregnant women who have sexual intercourse under the age of 19 are more at risk of developing hepatitis $B$ infection than mothers above 19 years $(\mathrm{AOR}=2.79 ; 95 \% \mathrm{CI}: 1.44-5.40) .{ }^{15}$ This is likely because women who marry at a young age are less able to negotiate safe sex, and this increases susceptibility to sexually transmitted diseases such 
as HIV, hepatitis, cervical cancer and many other diseases. ${ }^{30}$ In addition, women who marry at a young age tend to have lower levels of education, and lower level of knowledge regarding basic reproductive health including the prevention of HIV and hepatitis B. ${ }^{30}$

The limitation in this study is that the HBsAg status was examined when women were already pregnant and the onset of hepatitis $B$ infection was unknown. There is a possibility that the respondents had been infected with hepatitis $B$ before the occurrence of the exposures investigated in this study. Furthermore, HBsAg examination in this study used a dipstick with a sensitivity level of $>99.0 \%$ and a specificity of $97.09 \%$ so that there was the possibility of false negatives by $1 \%$ and false positives by $3 \%$. This study was carried out limited only in the working area of Pringgasela Public Health Center so that the findings cannot be extrapolated to the wider population.

\section{CONCLUSION}

Risk factors for hepatitis B in pregnant women are husbands who have worked abroad, the age of first marriage at 19 years or younger and the frequency of husband's marriage more than one time. Whereas the history of mothers working abroad, parity, history of miscarriage, frequency of maternal marriage and history of injecting were not found to be risk factors for hepatitis B infection in pregnant women. Prevention initiatives need to be undertaken including the vaccination and education of workers who will work abroad. In addition, education should be enhanced on the use of condoms, the risk of having multiple sexual partners and the risk of early marriage.

\section{ACKNOWLEDGEMENT}

We would like to thank the Head of Pringgasela Public Health Center, respondents and others who have assisted the implementation of this study.

\section{REFERENCES}

1. World Health Organization. Global Hepatitis Report. France; 2017.

2. World Health Organization. Hepatitis B. (serial online), [cited 2018 Feb. 06]. 2018. Available from: http://www. who.int/en/news-room/fact-sheets/detail/hepatitis-b.

3. Cahyono SB. Hepatitis B. $1^{\text {st }}$ edition. Sri I, editor. Yogyakarta: Kanisius; 2010. 1-114.

4. Ministry of Health of Indonesia. 150 ribu orang potensial alami hepatitis kronis [150 thousands people potentially suffer from chronic hepatitis]. (serial online), [cited 2018 Sep. 07]. 2017. Available from: http://www.depkes. go.id/150-ribu-orang-potensial alami-hepatitis-kronis. html.
5. Pringgasela Public Health Center. Hasil pemeriksaan deteksi dini hepatitis B pada ibu hamil [Results of hepatitis B early detection among pregnant women]. Selong; 2016. Unpublished.

6. Anaedobe CG, Fowotade A, Omoruyi CE, Bakare RA. Prevalence, socio-demographic features and risk factors of hepatitis B virus infection among pregnant women in Southwestern Nigeria. The Pan African Medical Journal. 2015; 20(6206): 406.

7. Alrowaily MA, Abolfotouh MA, Ferwanah MS. Hepatitis $B$ virus sero-prevalence among pregnant females in Saudia Arabia. The Saudi Journal of Gastroenterology. 2008; 14(2): $70-2$.

8. Metaferia Y, Dessie W, Ali I, Amsalu A. Seroprevalence and associated risk factors of hepatitis B virus among pregnant women in Southern Ethiopia: a hospital-based crosssectional study. Epidemiology and Health. 2016; 38: 1-7.

9. Nwachukwu NC, Iheukwumere I, Onyekwere VO. Seroprevalence of hepatitis B surface antigens (HBsAg) among pregnant women attending antenatal in Unth, Ituku Ozalla, Nigeria. International Journal of Arts \& Sciences. 2014; 7(3): 581.

10. Obi SN, Onah HE, Ezugwu FO. Risk factors for hepatitis B infection during pregnancy in a Nigerian obstetric population. Journal of Obstetrics and Gynaecology. 2006; 26(8): 770-2.

11. Onwere S, Chigbu B, Aluka C, Kamanu CI, Okoro O, P.E. Ndukwe C, et al. Risk factors for hepatitis B virus infection during pregnancy in South Eastern Nigeria. East African Medical Journal. 2012; 89(3): 89-93.

12. Umare A, Seyoum B, Gobena T, Mariyam TH. Hepatitis $B$ virus infections and associated factors among pregnant women attending antenatal care clinic at Deder Hospital, Eastern Ethiopia. PLoS ONE. 2016; 11(11): 1-11.

13. Frambo AAB, Atashili J, Fon PN, Ndumbe PM. Prevalence of HBsAg and knowledge about hepatitis B in pregnancy in the Buea Health District, Cameroon: a cross-sectional study. BioMed Central Research Notes. 2014; 7(394): 1-7.

14. Omilabu MA, Okunade K, Gbadegesin A, Olowoselu O, Olowule A, Ombilabu S. Seroprevalence of hepatitis B virus infection among pregnant women at the antenatal booking clinic of a tertiary hospital in Lagos Nigeria. Nigerian Journal of Clinical Practice. 2015; 18(6): 819-23.

15. Rabiu KA, Akinola OI, Adewunmi AA, Omololu OM, Ojo TO. Risk factors for hepatitis B virus infection among pregnant women in Lagos, Nigeria. Acta Obstetricia et Gynecologica. 2010; 89(8): 1024-8.

16. Zenebe Y, Mulu W, Yimer M, Abera B. Sero-prevalence and risk factors of hepatitis $B$ virus and human immunodeficiency virus infection among pregnant women in Bahir Dar City, Northwest Ethiopia: a cross sectional study. BioMed Central Infectious Diseases. 2014; 14(118): 1471-2334.

17. Li X, Zheng Y, Liau A, Cai B, Ye D, Huang F, et al. Hepatitis $B$ virus infections and risk factors among the general population in Anhui Province, China: An epidemiological study. BioMed Central Public Health. 2012; 12(1): 272.

18. Amtarina R, Arfianti A, Zainal A, Chandra F. Faktor risiko hepatitis B pada tenaga kesehatan Kota Pekanbaru [Risk factors of hepatitis B among health workers in Pekanbaru City]. Majalah Kedokteran Bandung. 2009; 41(3): 1-7.

19. Aini R, Susiloningsih J. Faktor risiko yang berhubungan dengan kejadian hepatitis B pada Pondok Pesantren Putri Ibnul Qoyyim Yogyakarta [Risks factors associated with hepatitis B prevalence at Ibnul Qoyyim Female Islamic Boarding School Yogyakarta]. Sains Medika. 2013; 5(1): 30-3.

20. Merry V. Pengelolaan hepatitis B dalam kehamilan dan persalinan (Tesis) [Management of hepatitis B during pregnancy and labor (Thesis)]. Semarang: Universitas Diponegoro; 2001.

21. Pusparini AD, Ayu PR. Tatalaksana persalinan pada kehamilan dengan hepatitis B [Management of labor in pregnancy with hepatitis B]. Jurnal Medula Unila. 2017; 7(2): $1-5$. 
22. National Authority for the Placement and Protection of Indonesian Overseas Workers. Data penempatan dan perlindungan tenaga kerja Indonesia tahun 2015 [Data of placement and protection of Indonesian overseas workers 2015]. Jakarta Selatan: National Authority for the Placement and Protection of Indonesian Overseas Workers; 2015.

23. National Authority for the Placement and Protection of Indonesian Overseas Workers. Data penempatan dan perlindungan TKI periode Januari s.d Februari 2016 [Data of placement and protection of Indonesian overseas workers period of January-February 2016]. Jakarta Selatan: National Authority for the Placement and Protection of Indonesian Overseas Workers; 2016.

24. Statistics Office of East Lombok District. Kabupaten Lombok Timur dalam Angka 2017 [2017 East Lombok District in Number]. Selong: Statistics Office of East Lombok District; 2017.

25. National Demographic and Family Planning Board. Survei Demografi dan Kesehatan Indonesia Tahun 2017 [The 2017 Indonesia Demographic and Health Survey]. Jakarta: National Demographic and Family Planning Board; 2018.

26. South Australian Maternal \& Neonatal Community of Practice. Clinical guideline hepatitis B in pregnancy. Australia; 2016.
27. Kandun IN. Manual pemberantasan penyakit menular [Manual of infectious diseases control]. $17^{\text {th }}$ edition. Chin J, editor. Jakarta; 2000.

28. Marschall T, Krämer A, Prüfer-Krämer L, Mikolajczyk R, Kretzschmar M. Erhöhen migrationen aus hohen und mittleren endemiegebieten die hepatitis B-prävalenz in Deutschland?. Deutsche Medizinische Wochenschrift. 2005; 130(48): 2753-8.

29. Zhang L, Wang Y, Huang Y, Wang Q, Nelson KE, Wang A, et al. Status of HBsAg seroprevalence in 15 million rural couples in China: a cross-sectional study. Scientific Reports. 2017; 42822(7): 1-7.

30. United Nations Children's Fund. Ending child marriage progress and prospects. New York; 2014.

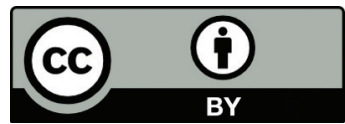

This work is licensed under a Creative Commons Attribution 